\title{
Nervous System Findings Link Group
}

National Cancer Institute

\section{Source}

National Cancer Institute. Nervous System Findings Link Group. NCI Thesaurus. Code C162035.

A sequence of characters used to link multiple nervous system findings to a single finding. 